\title{
Understanding Mud Volcano System Using Hele-Shaw (H-S) Experiment: Seismic Confirmation at East Java Mud Volcano
}

\author{
Muhammad Burhannudinnur ${ }^{1 *}$, Dardji Noeradi ${ }^{2}$ \\ ${ }^{1}$ Department of Geological Engineering, Universitas Trisakti, Jakarta, Indonesia. \\ 2 Department of Geological Engineering, Institut Teknologi Bandung, Bandung, Indonesia.
}

* Corresponding author: burhan@trisakti.ac.id

Tel.:+62811836263

Received: Oct 18, 2021; Accepted: Dec 27, 2021.

DOI: $10.25299 /$ jgeet.2021.6.4.7889

\begin{abstract}
Numerous researchers have carried out studies on the mud volcano system in East Java. However, there have been no experiments on the mud volcano system's mechanism, including overpressure confirmed by direct subsurface data. Therefore, this study aims to directly evaluate the mud volcano system's mechanism using the Hele-Shaw (H-S) experiment with the subsurface data confirmation. The H-S experiment utilized four primary materials: quartz sand diameter below $250 \mu \mathrm{m}$ and $320 \mu \mathrm{m}$ to analogize the porous layer. Gypsum flour clay is the ductile layer, while mud from the Kuwu and Kesongo Mud Volcanoes is the original material from nature. Wax repres ents impermeable material. The sealing layer is made of wax, and oxygen represents the natural fluids of the rock formation. The overpressured zone is created by pumping oxygen into a layer of quartz sand covered by a wax as an impermeable layer. Pressure is measured digitally, and the process is continuously recorded to produce traceable data. Each material was experimented on individually to determine the critical phase characteristics, valve fault structure geometry, and validation with seismic interpretation. The results indicate that the critical phase of the mud volcano system is characterized by the dome structure at the surface, with high intensify of gas and oil seepage. Piercement structure geometry is shown by plumbing of fluidization zone, which becomes shallower than before. Furthermore, each material's piercement structure geometry shows a consistent pattern, with differences in the density of the fault and pressure structures. Thus, the H-S experiment's validation with seismic interpretation shows a similar geometry in pressure structures and valve faults as the mud volcano system's migration paths.
\end{abstract}

Keywords: mud volcano system, Hele-Shaw, overpressured, valve fault, critical phase

\section{Introduction}

The process of a mud volcano system from the formation of source material rock, migration to the eruption, and its associated structures needs to be adequately understood. Analogous experiments with heleshaw allow us to see the process of the occurrence of a mud volcano system and describe the geometry of the evolving structure to be modeled. The geometry model of this structure will be compared with the geometry from below the surface using seismic data. This analog experiment assumes natural conditions are represented under these modeling conditions. In addition, the initial parameters of the experiment exclude the effect of initial temperature and pressure. Subsequently, The elements and processes in the generative, migration, and extrusion subsystems were formulated.

East Java is an area where research on mud volcano systems has often been carried out, including a study by Satyana on mud diapir and mud volcano around East Java to the Madura oil and gas fields, especially in the "F" field (Satyana and Asnidar, 2008). Meanwhile, Burhannudinnur discussed the characteristics of a unique mud volcano in East Java, including within the research area, and discussed the Kradenan Mud Volcano complex in great detail in terms of exploration prospects and risks (Burhannudinnur, 2012; Burhannudinnur et al., 2012). Mud gas play is a new exploration play for unconventional gas that can be found associated with the mud volcano system (Burhannudinnur,
2019). The mud volcano system in the Kradean and Kesongo areas has a potential geohazard risk. The area and depth of the potential geohazard risk area can be predicted by integrated analysis of the strain ratio and sedimentation rate distribution (Burhannudinnur, 2020)

An analog experiment continually develops to explain geological symptoms of structure-tectonics, sedimentation, and ground motion. Previous studies conducted a mud volcano analog experiment through the simple sandbox and fluid experiments. Generally, this experiment uses the principle of buoyancy, as in the diapir model. According to Price et al., 1990, analogous experiments of low-density materials' motion in high-density materials are an early concept developed for diapir modeling. In the sandbox experiment, the mud volcano material was modeled with silicon, for instance, salt diapir (Letouzey et al., 1990; Talbot, 1995). Thus, this modeling provides an overview of the pressure structure using diapir but cannot explain the fluid and pressure present in the mud volcano or the eruption mechanism.

An analog experiment was conducted with Hele-Shaw (H-S) to simulate the mud volcano system as well as extrusion mechanism, provide an analog enabling easier understanding of the extrusion process in nature, and as a validation test for seismic interpretation. Thus, the H-S modeling's results are the pressure structure and valve faults' geometry models and several simulations of the mud volcano extrusion mechanism. 
The Hele-Shaw (H-S) method is a thin glass box modeling, enabling the processes inside the glass box to be observed visually. H-S boxes are often used in material modeling to test physical material properties while sprayed, flowed, or under a specific temperature as well as pressure (Nermoen et al., 2010; Rigord et al., 2005). Researchers introduced this method for modeling glass grains' response to pressurized gas flow (Johnsen et al., 2008). The experiments by Rigord et al. (2005) developed a tool to study the response of a thin glass grain layer immersed in a slow-flowing liquid under controlled pressure, and the tool is designed to allow liquid flow from bottom to top. Subsequently, the liquid flow rate is measured and controlled to determine the turbulence effect. The thin layer of glass grains becomes unstable and unbalanced with increased liquid flow. This increase does not lift the entire thin layer of glass grain but forms a channel or column of the granular fluidization zone, connecting the bottom and top. The glass grains emerge to the surface to form eruptions similar to jets of water, deposited on the surface, with a hole diameter about 32 times the grain size.

Nermoen et al. (2010) also designed an experimental tool to study the fluidization process. The $\mathrm{H}-\mathrm{S}$ device in this study was vertically oriented, filled with $250 \mu \mathrm{m}$ glass beads, and injected with pressurized gas, with variations in the glass grain layer thickness and inlet diameter. Consequently, the fluidization zone forms a divergent cone in the form of a pressure structure. The surface's morphological characteristics on the pressure structure have similarities to morphology in nature, including mud volcanoes, hydrothermal, kimberlite pipes, or geysers symptoms.

Modeling with the Hele-Shaw (H-S) method implies making a tool intended to model the mud volcano system and obtain an overview of the valve fault formation mechanism, geological structural geometry of the mud's motion through the layer above, observe the geometry and material motion from the overpressure zone to the mud volcano extrusion. Furthermore, Hele-Shaw is a vertical modeling method assumed to represent the geological section of the research area. The initial condition of H-S modeling is static, and the pore pressure is under hydrostatic conditions.

\section{Methodology}

\subsection{Hele-Shaw Design and Manufacture}

In this study, the H-S equipment and methods were designed and modified based on reference tools provided by Rigord et al. (2005), Johnsen et al. (2008), and Nermoen et al. (2010).

The main equipment consists of an $\mathrm{H}-\mathrm{S}$ wall, support table, inlet, hose line, and a gas cylinder. Meanwhile, the supporting equipment includes a pressure measuring instruments, computers, BSR software, on-screen video recorders, cameras, digital scales, levelers, funnels, pipes, and calipers. The H-S wall is a tool made of two parallel glasses $100 \mathrm{~cm}$ long and $75 \mathrm{~cm}$ tall, separated by a distance of $0.8-1 \mathrm{~cm}$ at the bottom and closed at the two sides (airtight), and open at the top. Furthermore, the material, particularly the compressed gas, is modeled outward rather than out of the three sides. An inlet was installed $8 \mathrm{~cm}$ from the bottom to prevent gas from flowing along the sand or equipment bottoms. Fig. 1 shows the Hele-Shaw modeling scheme and set of tools and an example of the experiment implementation.

\subsection{Selection of Material Types}

The material selection and use in modeling referred to the reports of several related research, including sandbox modeling at the Geodynamic Engineering Geology Laboratory, Faculty of Earth Sciences and Technology, Bandung Institute of Technology, referring Mazzini et al., (2009). In previous studies, material selection considered several factors: low cohesiveness and bearing capacity, brittle and ductile materials, easy-to-form structures, high porosity, safety, and ease of obtaining materials. Table 1 shows some materials variations used in $\mathrm{H}-\mathrm{S}$ modeling and sandbox modeling, while Fig. 1 shows a simplified diagram of H-S modeling tools installation.

Table 1. Material variations in H-S modeling and sandbox

\begin{tabular}{|c|c|c|c|c|c|c|}
\hline Researcher & Material Type & $\begin{array}{l}\text { Material layer } \\
\text { density (gr/cc) }\end{array}$ & $\begin{array}{l}\text { Material } \\
\text { density (gr/cc }\end{array}$ & $\begin{array}{l}\text { Grain Size } \\
(\mu \mathrm{m})\end{array}$ & $\begin{array}{l}\mathrm{K} \\
(\mathrm{mD})\end{array}$ & $\begin{array}{l}\text { Porosity } \\
(\%)\end{array}$ \\
\hline \multirow{2}{*}{$\begin{array}{l}\text { Hele-Shaw } \\
\text { (Nermoen et al., } \\
\text { 2010) }\end{array}$} & glass granules & 1,547 & 2,460 & $280 \pm 50$ & 120 & 37,11 \\
\hline & Oxygen & & & & & \\
\hline $\begin{array}{l}\text { Sandbox (Sapiie } \\
\text { and Hadiana, 2007) }\end{array}$ & quartz sand & 1,500 & & 250 & & \\
\hline \multirow[t]{2}{*}{$\begin{array}{l}\text { Hele-Shaw (Rigord } \\
\text { et al., 2005) }\end{array}$} & glass granules & 1,530 & 2,190 & $\begin{array}{l}80-400 \\
\text { and } 280 \pm 50\end{array}$ & 26 & 30,14 \\
\hline & water & & & & & \\
\hline \multirow{4}{*}{$\begin{array}{l}\text { Sandbox } \\
\text { modification } \\
\text { (Mazzini et al., } \\
2009 \text { ) }\end{array}$} & silica granules & & & $50-100$ & & \\
\hline & Chinese clay & & & & low & \\
\hline & glass granules & & & $118-380$ & & \\
\hline & air & & & & & \\
\hline \multirow[t]{4}{*}{ This research } & quartz sand & 1,500 & & $250-320$ & & \\
\hline & $\begin{array}{l}\text { Mud from the Kuwu and } \\
\text { Kesongo mud volcanoes } \\
\text { Oxygen }\end{array}$ & 1,453 & $\begin{array}{l}2,560 \\
\text { (dry) }\end{array}$ & $1-50$ & & \\
\hline & wax & & & & & \\
\hline & gypsum & & & $<100$ & & \\
\hline
\end{tabular}




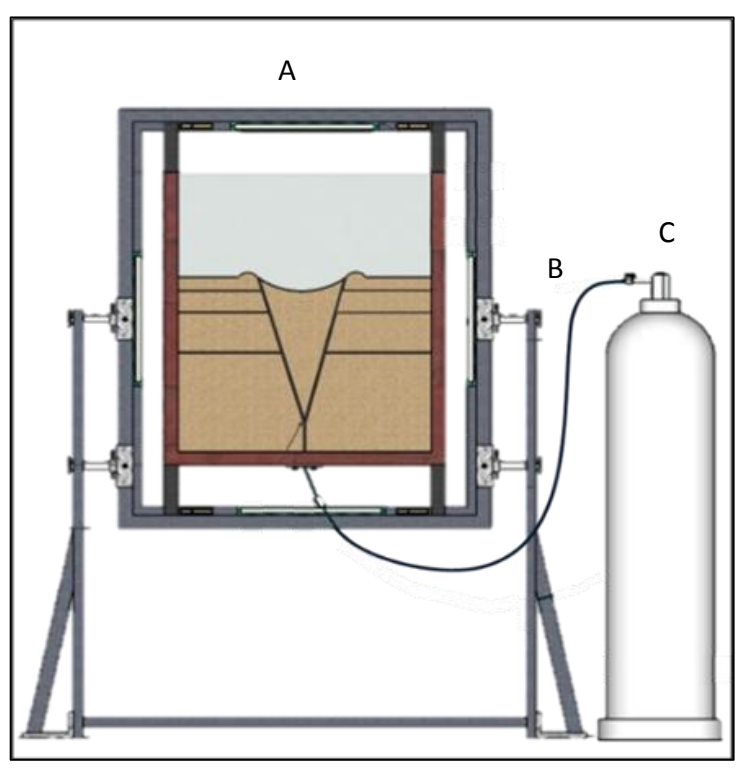

Fig. 1: Simplify diagram of the main H-S modeling tools installation (A) Hele-Shaw kit with quartz sand filling; (B) Pressure cable with digital pressure record; (C) High-pressure oxygen gas cylinder.

The materials used in this experiment were assumed to represent natural material conditions, and the details are outlined below.

(1) Quartz sand below $250 \mu \mathrm{m}$ and $320 \mu \mathrm{m}$ diameter to model layers with high porosity, low cohesiveness, low bearing capacity, assisted by the Geodynamic Laboratory, Geological Engineering Department, Faculty of Earth Sciences and Technology (FITB), Bandung Institute of Technology.

(2) Gypsum flour was assumed to represent a more ductile layer and was purchased from a chemical store.

(3) Mud from the Kuwu and Kesongo mud volcanoes containing different water and material represent the actual material condition in nature. Mud from Kuwu (sample no B-80) has a composition dominated by smectite, $95 \%$ clay grains, and inherent moisture by $11.5 \%$. Meanwhile, mud from Kesongo (sample no B-81) is more granular, has almost equal kaolinite and illite content, and has a $6 \%$ inherent moisture.

(4) Waxes were obtained from chemical shops and used to create impermeable coatings or insulation.

(5) Oxygen represents natural fluids as material released during formations to create an overpressured zone for safety reasons and is not adsorbed by granules.

\subsection{Equipment Performance Testing}

This test is necessary to determine the leakage and the $\mathrm{H}$-S equipment's ability to accept pressure, the sensitivity of pressure changes towards the experimental material layers' height variations, and the distance between the glass at the middle and edges. The test measured the pressure at different material layer heights for the same material type from the inlet top end. The material used was loose quartz sand measuring $250 \mu \mathrm{m}$ with layer height $(\mathrm{h})$ measured from the inlet end ranging between 10 and $40 \mathrm{~cm}$.

Data recording began with assembling the modeling equipment for this test, as shown in Fig. 1. The supporting equipment to be made is outlined below.
(1) Digital Extech 750 (data logger) pressure meter with $200 \mathrm{~Pa}$ resolution for digital pressure measurement.

(2) Laptops and software required to record data.

(3) Camera, with the ability to record 30 frames per second for video recording to record geometry and process the fluidized zone

(4) High pressure oxygen gas cylinder $(200 \mathrm{~kg} / \mathrm{cm} 2)$.

(5) Flexible pipe with a size of $4 \mathrm{~mm}$, hole diameter 2.5-3 mm, and able to withstand pressures up to 50 psi along with the connector.

(6) BSR software to record and save the data

(7) Preparation of other supporting tools, including digital scales and rulers.

(8) Preparation of modeling materials (quartz sand, mud, and wax).

In each experiment, the material used was weighed to ease the thickness control, then poured slowly through the funnel from the top to the desired height (h), and measured from the inlet's end. The sand is leveled rather than compacted according to height and made layer by layer as required. Subsequently, high oxygen gas pressure was injected into H-S through the inlet. The oxygen flow rate $(Q)$ was controlled at a constant flow rate. The valve was opened slowly to avoid turbulence in the material, located near the flow meter, $8 \mathrm{~cm}$ away from the gas cylinder. Meanwhile, the pressure (P) was recorded at a T-junction, 8 $\mathrm{cm}$ away from the inlet, using an Extech pressure meter. In this modeling, the gas input was controlled manually, while the pressure variations measurement was carried out automatically by an Extech pressure meter. In addition, digital images were recorded at a rate of 30 frames per second with the high-resolution Olympus VG-140 camera; 14 megapixels; $5 x$ wide; and optical zoom by $4.7-23.5 \mathrm{~mm}$, and 02 entered slowly, increasing until deformation occurred in the layer above. The pressure in the model increased to form a high pressure or fluidization channel up to $8.5 \mathrm{kPa}$, before erupting, then reducing to $7.0 \mathrm{kPa}$. Critical phase condition refers to the time of highest pressure before erupting. Fig. 2 shows an example of the recording results and the pressure profile. The equipment's test results did not leak, the gas continued to flow, and the distance between the Hele-Shaw glass wells did not change.

Meanwhile, the subsequent test measures pressure at various sand heights to test the equipment and material sensitivity. The tool has a sensitivity and readiness to perform further experiments, even with the increase in layer height thickness or pressure. The distance between the glass walls was measured with a caliper to determine the distance stability during the test. The H-S equipment is then suitable for use in cases where there are very small or no changes in distance.

Fig. 3 shows the test results, and the graph of pressure on material layer height shows a linearly proportional relationship with regression reaching 0.917 . This high regression indicates that the Hele-Shaw model equipment is functioning correctly and sensitive to pressure, with changes in the layer height. The sediment height (h) further increases critical pressure, while the distance between the glass in the middle extended less than $0.02 \mathrm{~mm}$ at a $32 \mathrm{~cm}$ layer height. Thus, the change in length is minimal, indicating the glass is strong enough to withstand the material and consequent pressure; therefore, there is no significant volume change in the Hele-Shaw tool. 


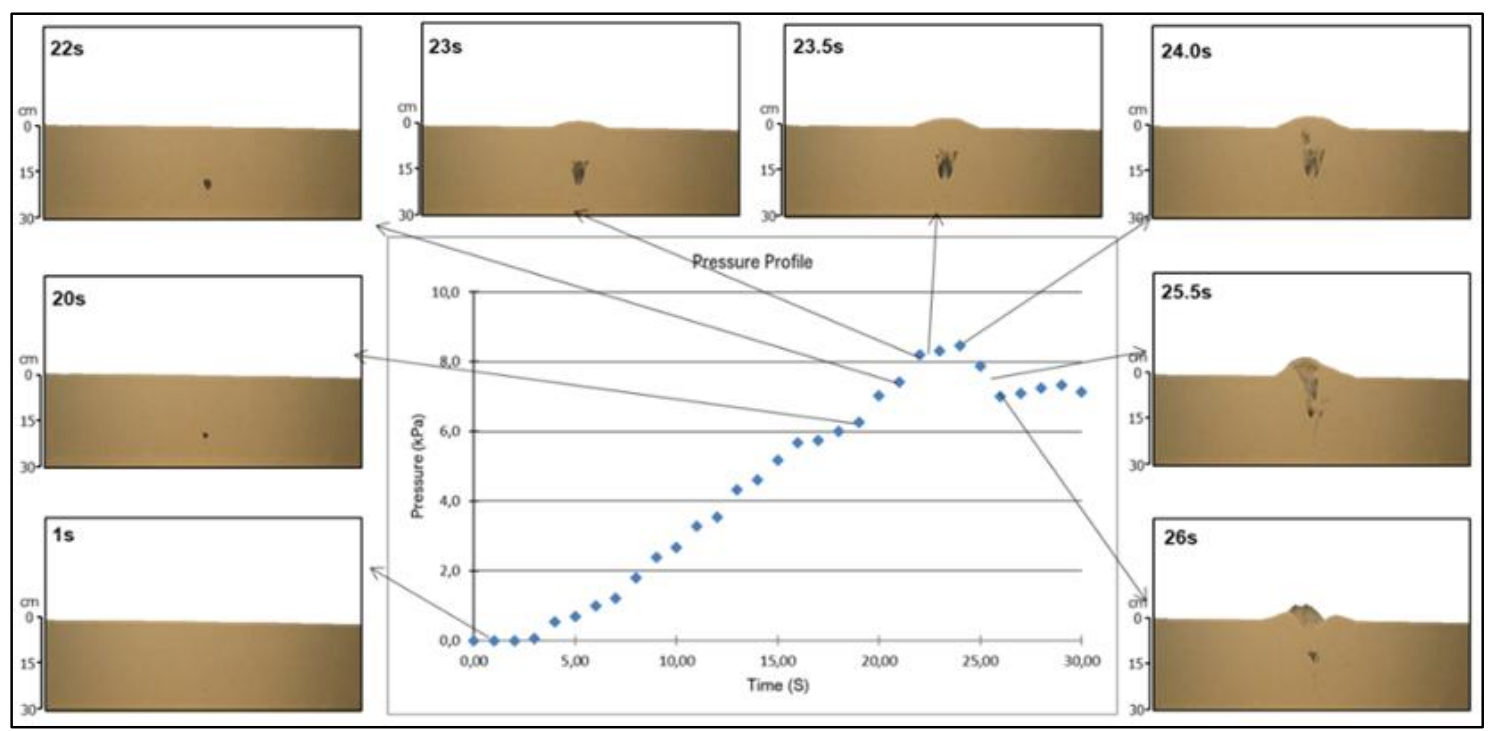

Fig. 2: An example of the pressure profile experiment (P) results on the material height measured from the inlet tip to the material layer's surface $(\mathrm{h}=17 \mathrm{~cm})$. This figure shows the development of quartz sand behavior during the initial oxygen injection until eruption, from $1 \mathrm{~s}$ to 26s. The model's pressure increases to form a high pressure or fluidization channel until $8.5 \mathrm{kPa}$, before the eruption, followed by a reduction to $7.0 \mathrm{kPa}$.

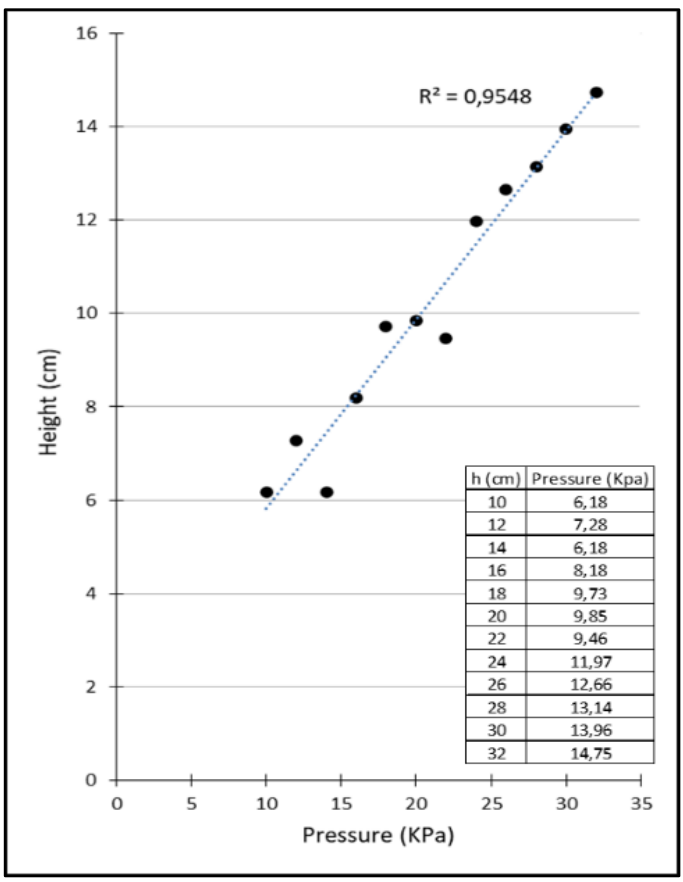

Fig. 3: Graph of equipment testing. The pressure increases as the layer height $(\mathrm{h})$ get thicker, indicating the equipment did not leak during the experiment and is suitable for modeling.

\section{Result and discussion}

\subsection{Experiment with Material Variations}

This experiment aims to determine the material response to the injection of compressed gas from the bottom. The method replaces the experimental material and records pressure data and a video from the beginning, where oxygen is first injected until an eruption occurs. Experiments were conducted on four materials, including $80 \mu \mathrm{m}, 250 \mu \mathrm{m}$, and $320 \mu \mathrm{m}$ size quartz sand, gypsum, and mud from the Kesongo and Kuwu mud volcanoes.

The four materials showed the same response after pressure reached a critical condition by forming pressure and dome structure on the surface (Fig. 4). However, the use of mud in this modeling responds differently from the other three materials. The pressure structure and fluidization zone geometric developments are not observable while using mud. The mud material is not used to model the pressure structure geometry in the subsequent stage.

\subsection{Critical Phase Characteristics}

The H-S section's critical pressure pattern and geometric expression are observable in this experiment. Based on experiments and observations from the model, the critical pressure phase's characteristics in the H-S model are obtained, as outlined below.

(1) The release of small gas and sand eruptions at numerous points, with the gas eruption's position on the surface changing and a fluidization channel visible below the surface.

(2) The dome structure found on the experimental layer's surface is associated with a lot of gas seepage. The fluidization zone's position becomes shallower in-depth, increasing to a more superficial level. In the H-S cross-section, fluidization channels are seen by pressurized gas passage

Fig. 5 illustrates the model characteristics in the critical pressure phase, and these characteristics apply to field and subsurface data in an integrated manner. 


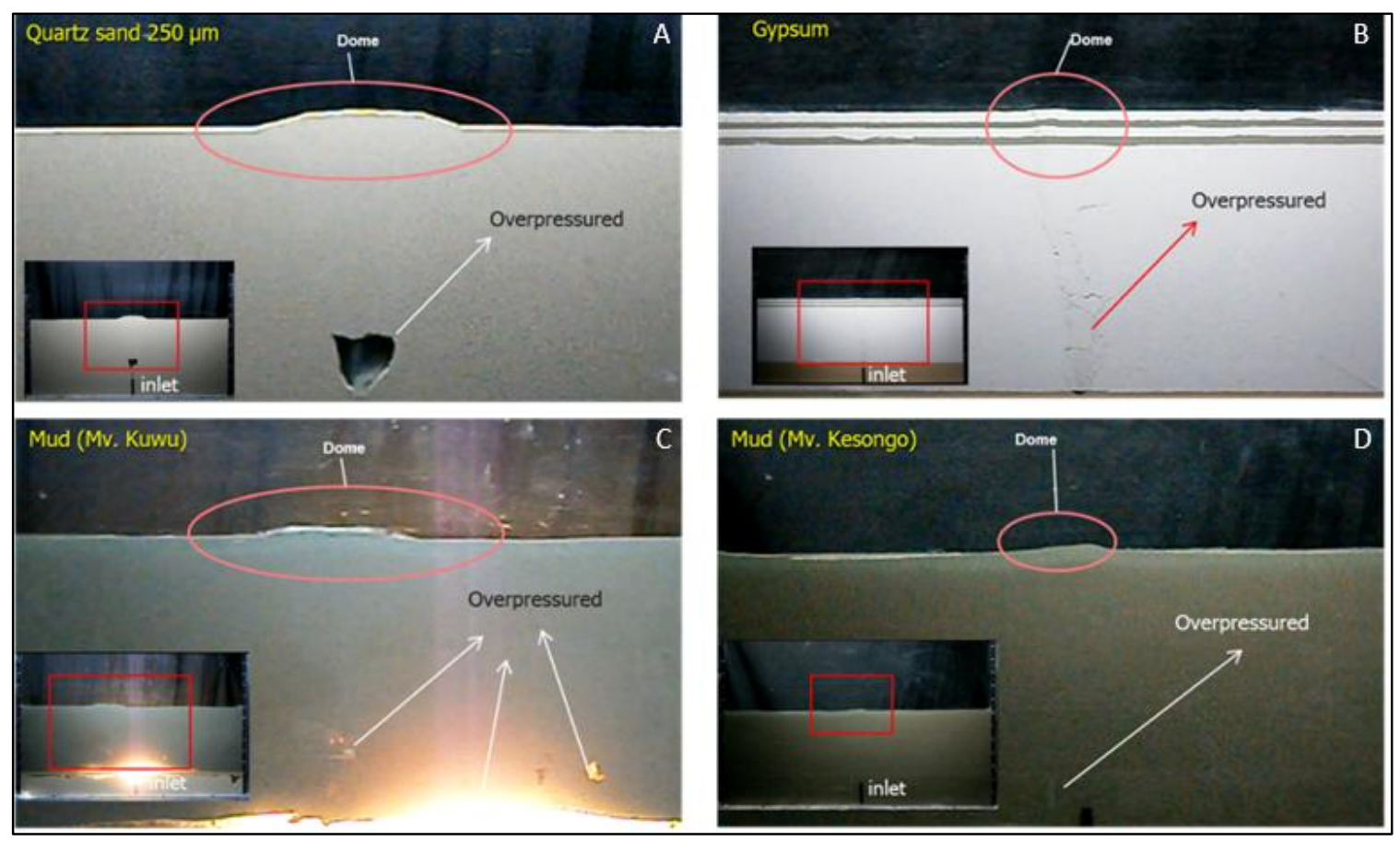

Fig. 4: Experiment with four types of materials. The result forms the same structure at a critical pressure, a dome structure on the surface.

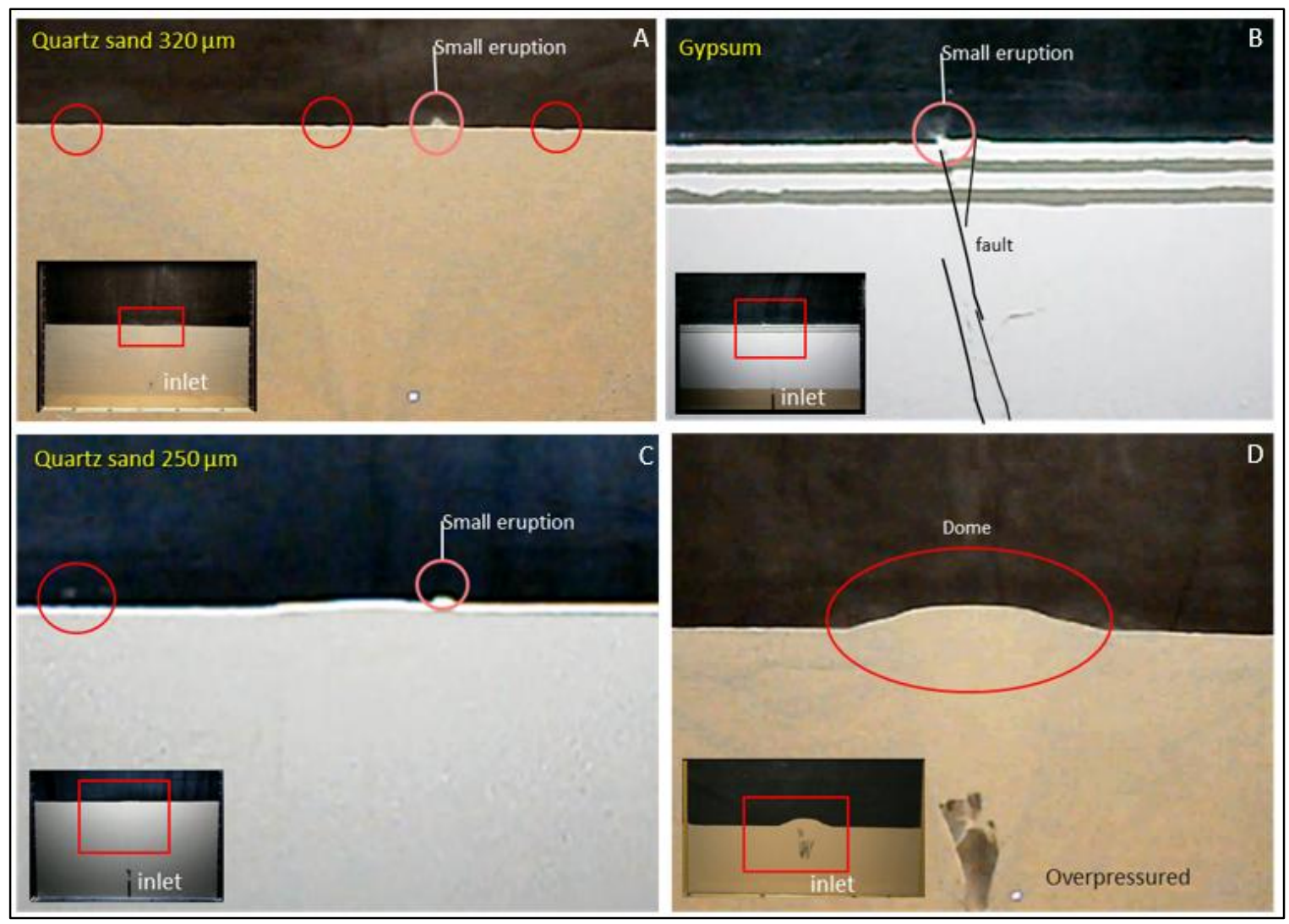

Fig. 5: Characteristics of a critical phase on the surface. (A) A small gas burst at several points, often with a pressure structure at the bottom. (B) Gas seepage next to the sloping dome, resulting from the breakthrough. (C) Another example of gas seepage. (D) Dome structures on the surface are associated with gas seepage.

\subsection{The Geometry of Pressure Structures}

The development of pressure/piercement structures has been tested in three materials, $250 \mu \mathrm{m}$ and $320 \mu \mathrm{m}$ quartz sand and gypsum. Fig. 6. A to L show the development from initial conditions to eruption in the three materials. The pressure structure's detailed geometry for the three materials shows a consistent pattern development, with differences in the fault and pressure structures' densities and widths. Therefore, structure intensity is tighter in finer gypsum and quartz sand (250 
$\mu \mathrm{m})$. In gypsum material, a fan-like structure tends to develop and occur in more than one fluidizing channel.

Repeated experiments were carried out by recording from the start of oxygen injection to material extraction to determine the pressure structure's consistency. Furthermore, a description consistent with the presence of a positive pressure structure similar to a "positive flower structure" was obtained.

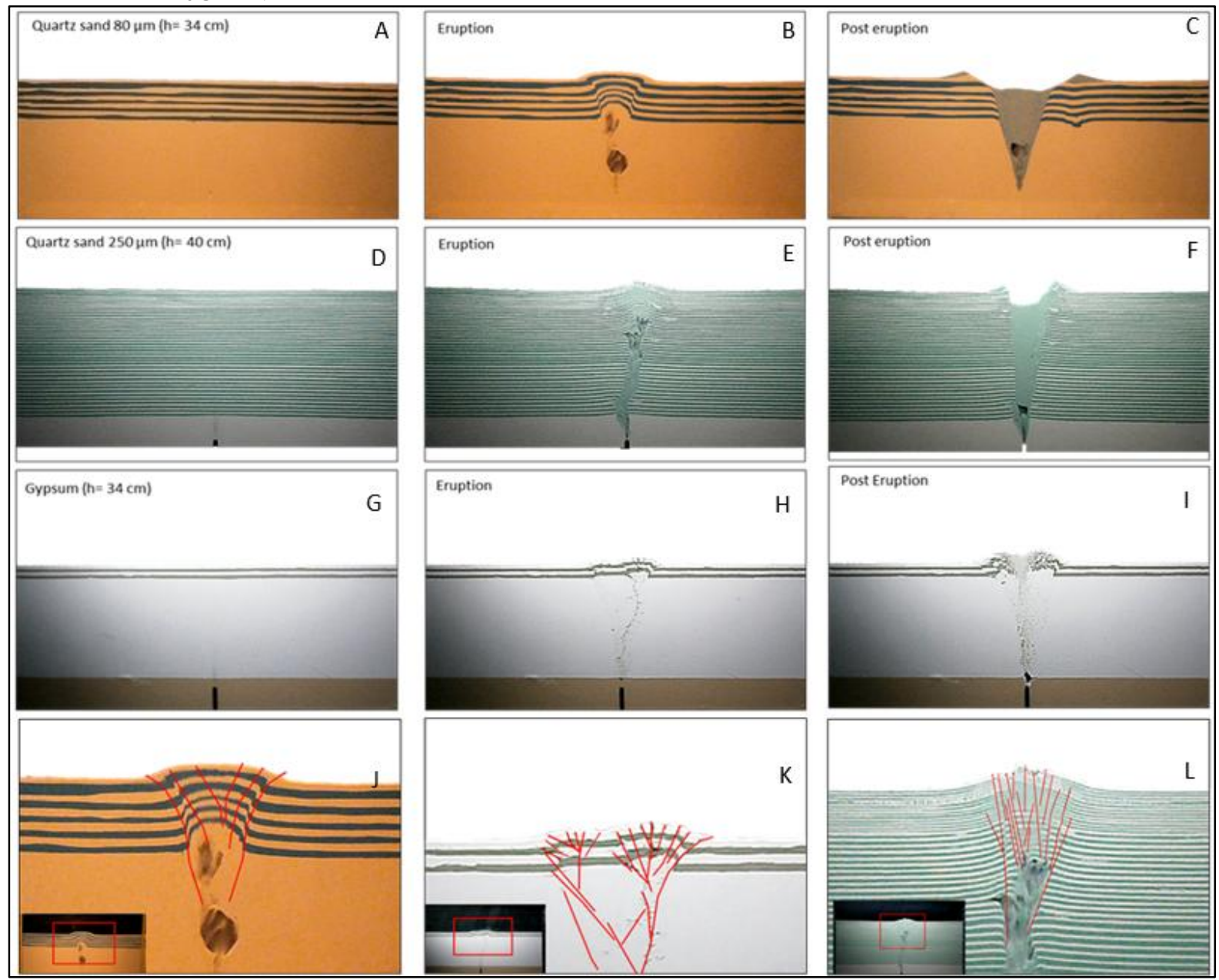

Fig. 6: Fault geometry variations of piercement structure in eruption and post-eruption models for various experimental materials. (A, B, and C) fault geometry in $320 \mu \mathrm{m}$ quartz sand. (D, E, and F) fault geometry in $250 \mu \mathrm{m}$ quartz sand. (G, H, and I) fault geometry in gypsum.

$(\mathrm{J}, \mathrm{K}$, and $\mathrm{L}$ ) show details of fault geometry patterns in each material. Surface subsidence occurs after the eruption but remains an overpressured zone in the deep zone.

\subsection{Validation of Seismic Interpretation with Hele-} Shaw Model

The validation model was performed using a modeling scale of $1 \mathrm{~cm}$ representing 100 meters. The thickest sediment in Kradenan is 3,000 m (Burhannudinnur, 2012); however, the Sidoarjo counterpart is not obtainable from seismic data but was estimated to be over $4,000 \mathrm{~m}$ from the region to 15,000 feet (Kusumastuti et al., 1999; Burhannudinnur et al., 2012). In addition, the material layer height measured from the top of the inlet is $30 \mathrm{~cm}$. HeleShaw modeling is basically vertical and close to $2 \mathrm{D}$, however, in this experiment, a lateral scaling referring to sandbox modeling, where $1 \mathrm{~cm}=1 \mathrm{~km}$ was used, and the length of $100 \mathrm{~cm}$ represents a route passing through Kradenan or Sidoarjo areas (40-70 km).

Validation of valve fault geometry in Sidoarjo is represented by XX-07 (Fig. 7) and XX-126 (Fig. 8) seismic lines. Fig. 7 shows the main fault in green. The main faults develop into small ones while cutting the strong reflection, forming a pattern similar to a small fan's radius. The seismic reflection forms a positive curve as a pressure structure. According to Fig. 7, the seismic section's fault and pressure structure show similar geometries and patterns compared to the geometry of the modeling results. Meanwhile, Fig. 8 shows the seismic interpretation's validation, using an analog model with Hele-Shaw in the Sidoarjo area, for random reflection patterns and pressure structures similar to shear fault geometry with positive flower structure geometry.

The formation of seismic pressure structure in the Kradenan area was selected by two routes, XX-08, under Banjarlor and Cangkringan (Fig. 9), and XX-09 (Fig. 10), under Crewek. Fig. 9 shows a vertical channel with random characters, representing a mud material supply channel and a pressure structure, closely similar to the H-S model. Also, the XX-09 seismic line through the Crewek Mud Volcano is highly similar and a fitting representation of the seismic and model from Hele-Shaw. 


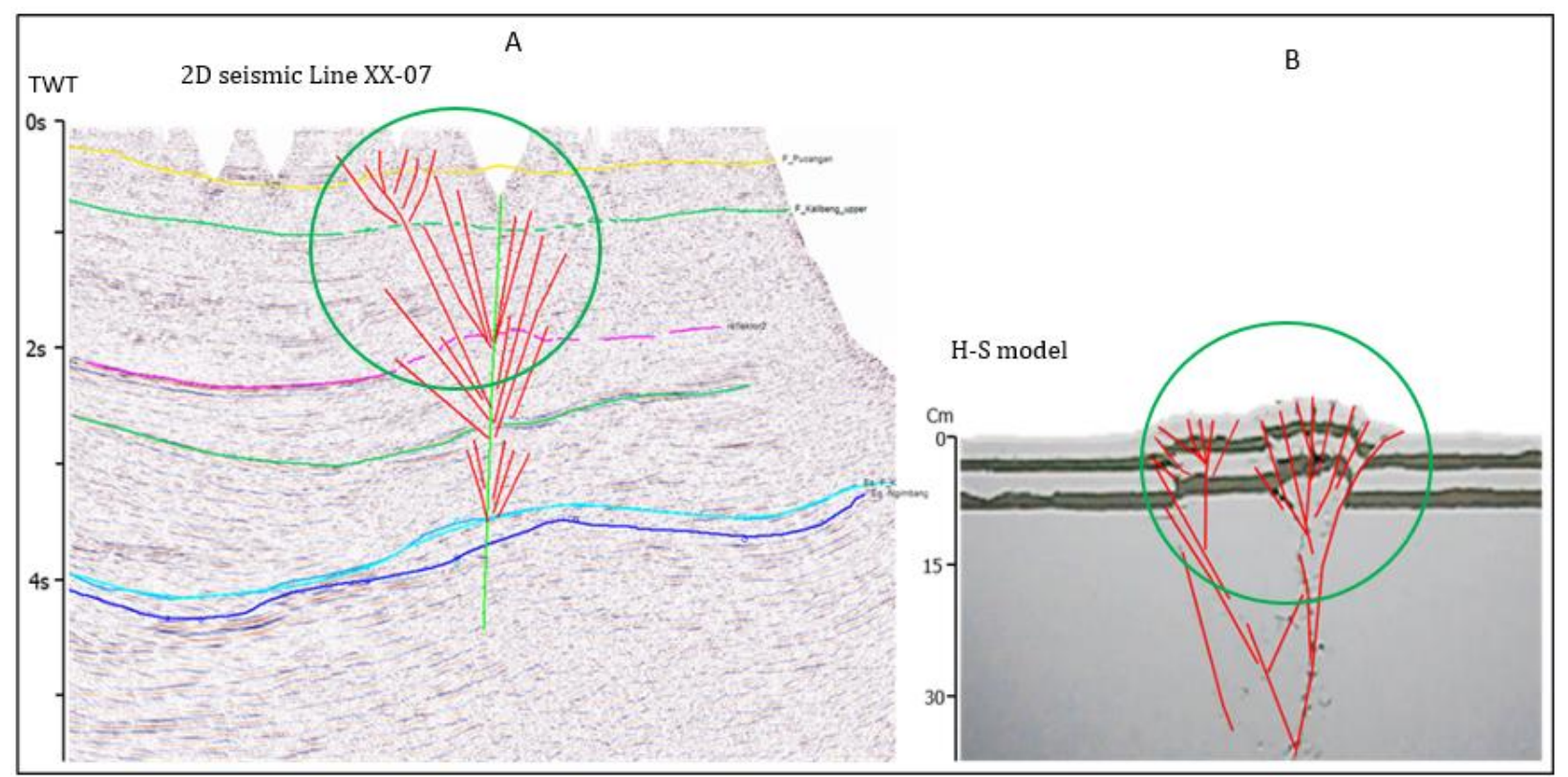

Fig. 7: (A) Valve fault in seismic data XX-07, Sidoarjo. (B) valve faults in H-S models. The upward pressure pattern obtained by pushing/piercing the material through the main fault causes a series of valve faults. Minor faults are closely similar between seismic and H-S models. The pressure migration causes a new valve structure above other points (green circles) occurring in models and seismic.

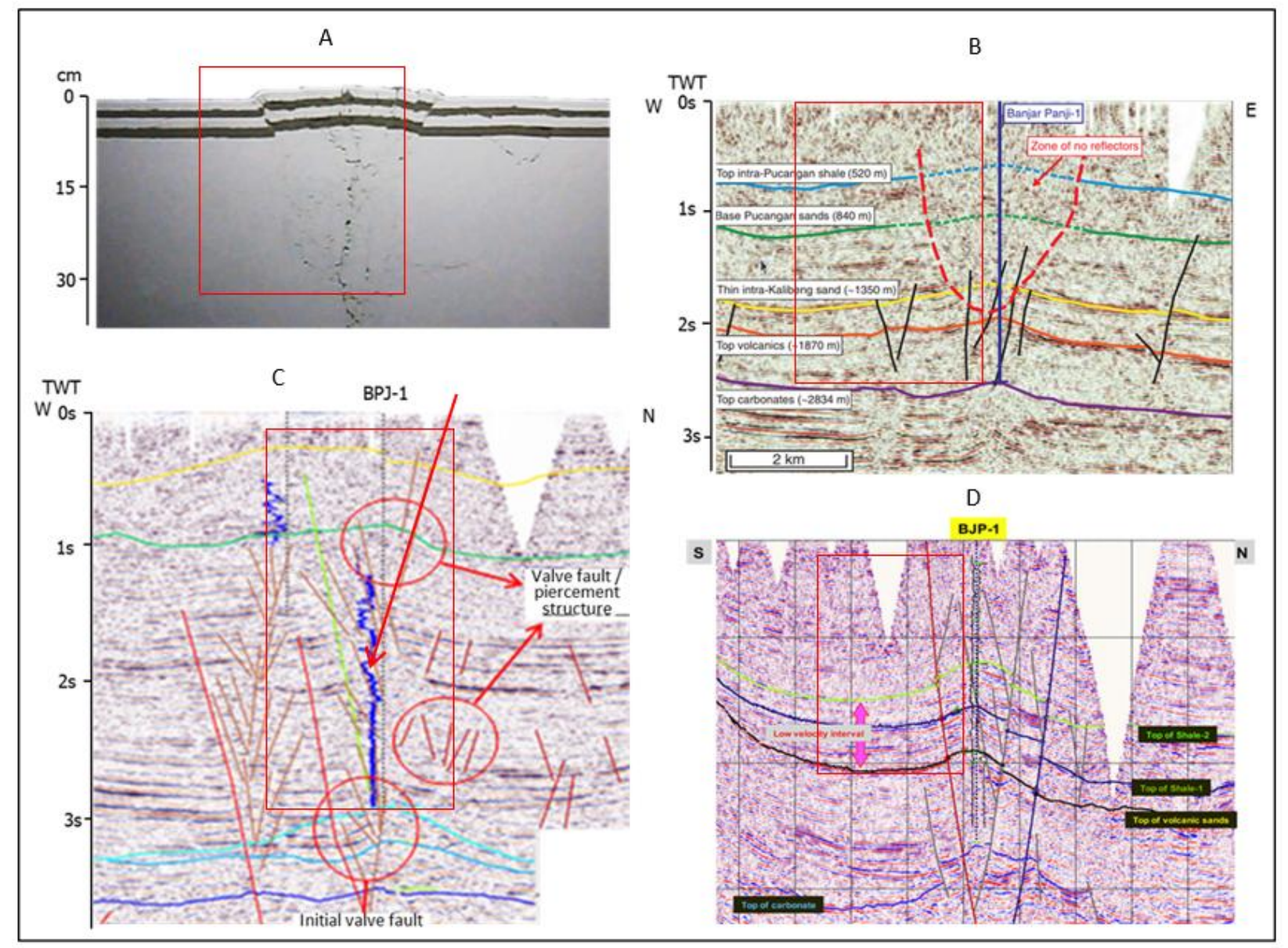

Fig. 8 (A): Fault's development on the is possibly modeled with H-S. (B) Interpreted seismic W-E Banjarpanji-1 Well ((Tingay, 2014)). (C) Valve fault geometry/piercement structure around BJP-1. (D) Interpreted seismic data S-N BJP-1well (Sawolo et al., 2009). 


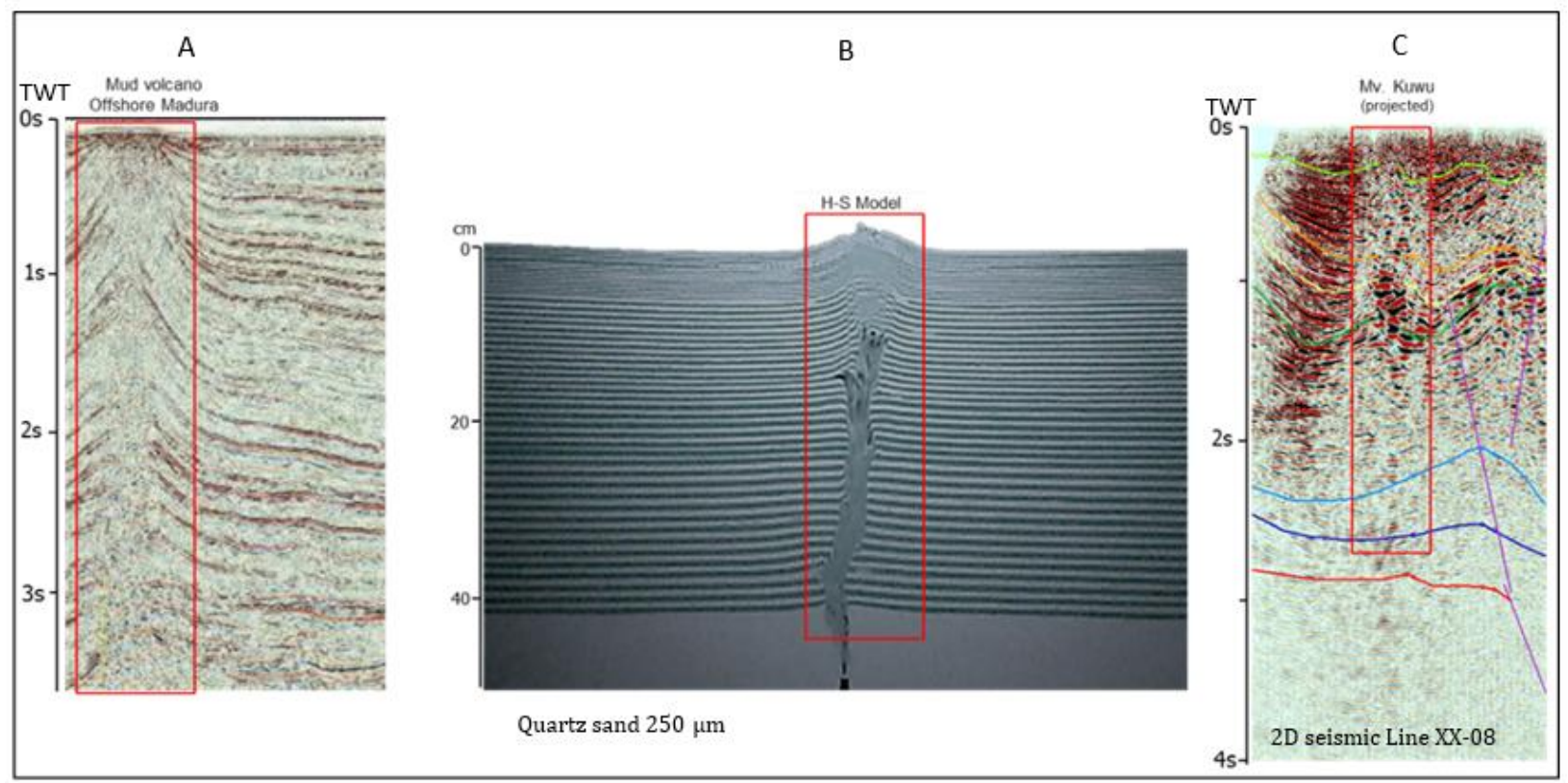

Fig. 9: (A) Mud volcano system at Madura offshore (Istadi et al., 2012). (B) Mud volcano system in H-S model. (C) Seismic line XX-08 onshore seismic around Mv. Kuwu, East Java. They have a similar structural pattern, vertical plumbing from random reflection with dome or pressure structures at the top, bounded by main faults.

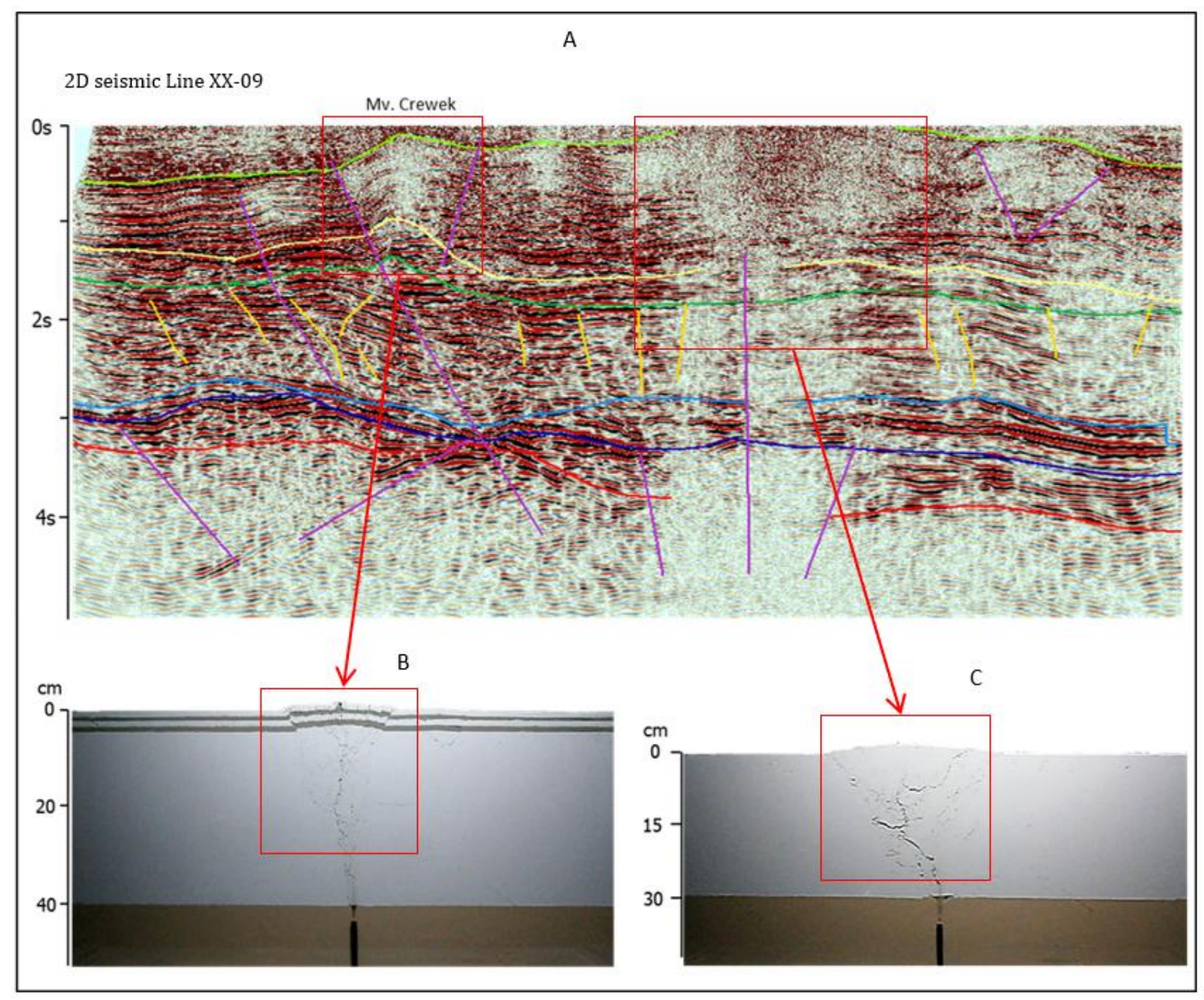

Fig. 10: The interpreted seismic passing XX-12 (A) through the Crewek Mud Volcano shows seismic's random zones matching the H-S model geometry (B, $\mathrm{C}$ red box). 


\subsection{H-S Modeling of Overpressure Materials Lateral Movement}

$\mathrm{H}-\mathrm{S}$ Lateral Movement modeling aims to understand the occurrence of lateral migration of overpressured materials. The initial condition of the model is to make two inlets; the first inlet is at the bottom of the model, while the second is on the side of the sealing layer above the overpressured layer. This second inlet represents a minor fault as a migration path. The position of the minor fault (second inlet) has an impermeable layer above the porous layer 12 $\mathrm{cm}$ from the projection of the first inlet.

Based on the results, after being injected with oxygen, the quartz sand layer under the sealing layer slowly forms an overpressured zone between the quartz sand and wax layers. Furthermore, the push or flow changes upward and moves sideways until a small fault is found. These faults in the sealing layer become channels for the overpressure material to rise and push upward, forming valve faults and pressure structures, then moving and extruding to the surface (Fig. 11). Lateral movement is also caused by compacting differences in the same material layer. Fig. 12. B shows the difference of gypsum compaction at the middle and edges, causing the gas not to penetrate sideways, then upwards, rather than vertically.

Lateral movement of material with overpressure in nature also occurs under the surface. For instance, the seismic route XX-10 passes through Kesongo Mud Volcano, and in the Ngimbang Formation, overpressure and connection by faults form the Kesongo Mud Volcano on the surface. This fault also acts as an overpressure migration route into the zone above. Meanwhile, the Tawun formation forms a large overpressure zone, reaching $7 \mathrm{~km}$ below the younger formation sealing layer. In the Tawun formation, the overpressure zone is characterized by a random and blurry reflection pattern, forming an irregular geometry similar to a chamber or pocket. Another distinctive feature is the presence of Vbright around the channel and minor faults and polygonal faults in the Tawun formation outside the reflection pattern random geometry (Fig. 13). According to Fig. 14, the Hele-Shaw modeling confirms overpressure conditions are spread under the sealing layer before finding faults or fractures or moving forward in search of a weaker zone.

The presence of an overpressured zone in the Ngimbang Formation from random seismic reflection data supports the existence of fossil data from rock fragments with Oligocene ages, and this age is in accordance with the Ngimbang-Kujung Formation. Also, the main faults serving as the material supply channel are seen in the seismic data of mud volcanoes and are supported by petrographic data of rock fragments with scour, micro folding, and stylolite structures, showing strongly deformed rock samples.

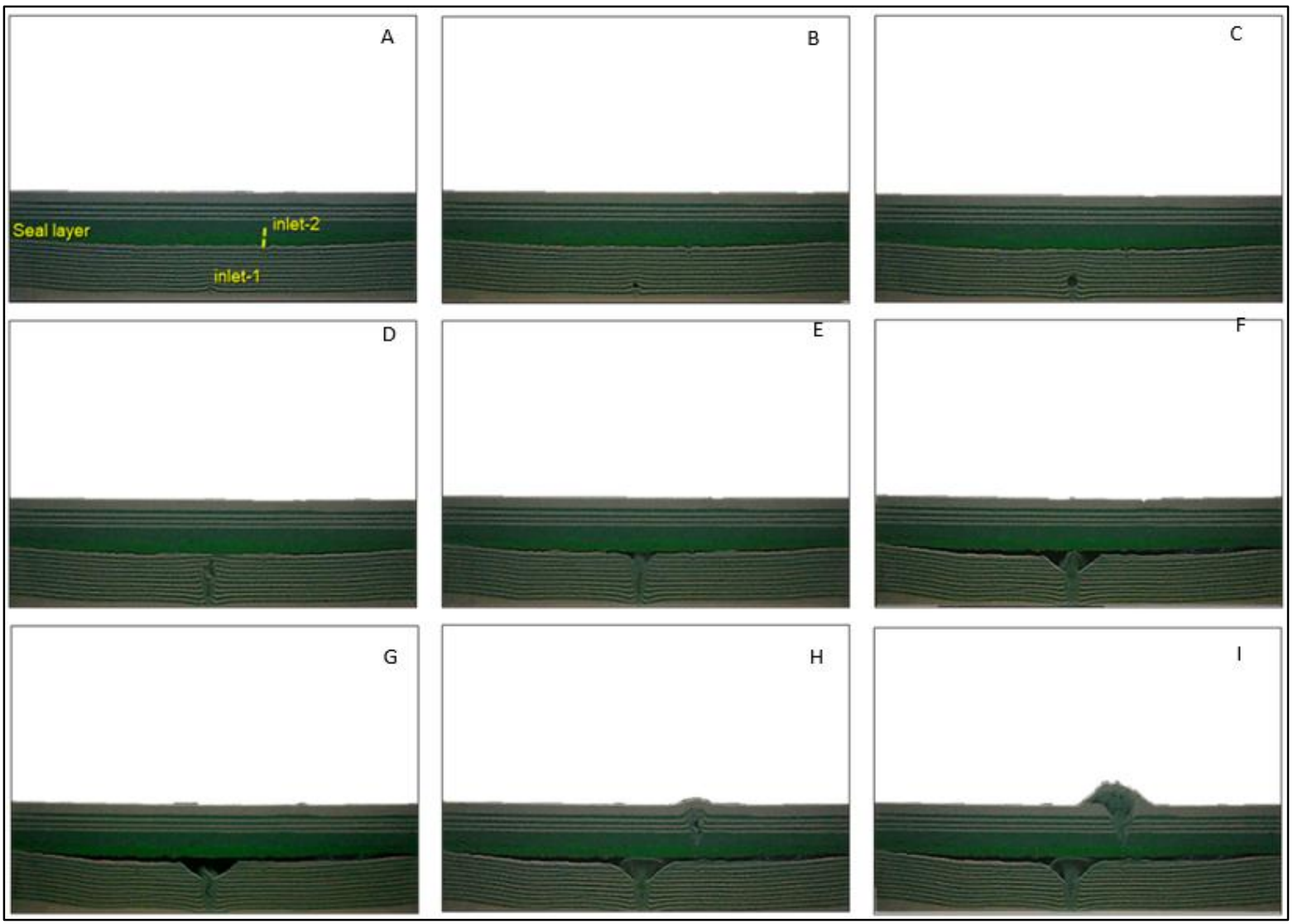

Fig. 11: (A) Initial model of H-S sand layer sealing layer insert (green wax), minor fault as the second inlet, with h- $22 \mathrm{~cm}$. (B-E) Highpressure gas penetrates the layer below. (F, G) The gas presses move sideways and concentrate under the seal. (H) The gas penetrates minor faults, second inlet. (I) Fluidization in the second inlet. 


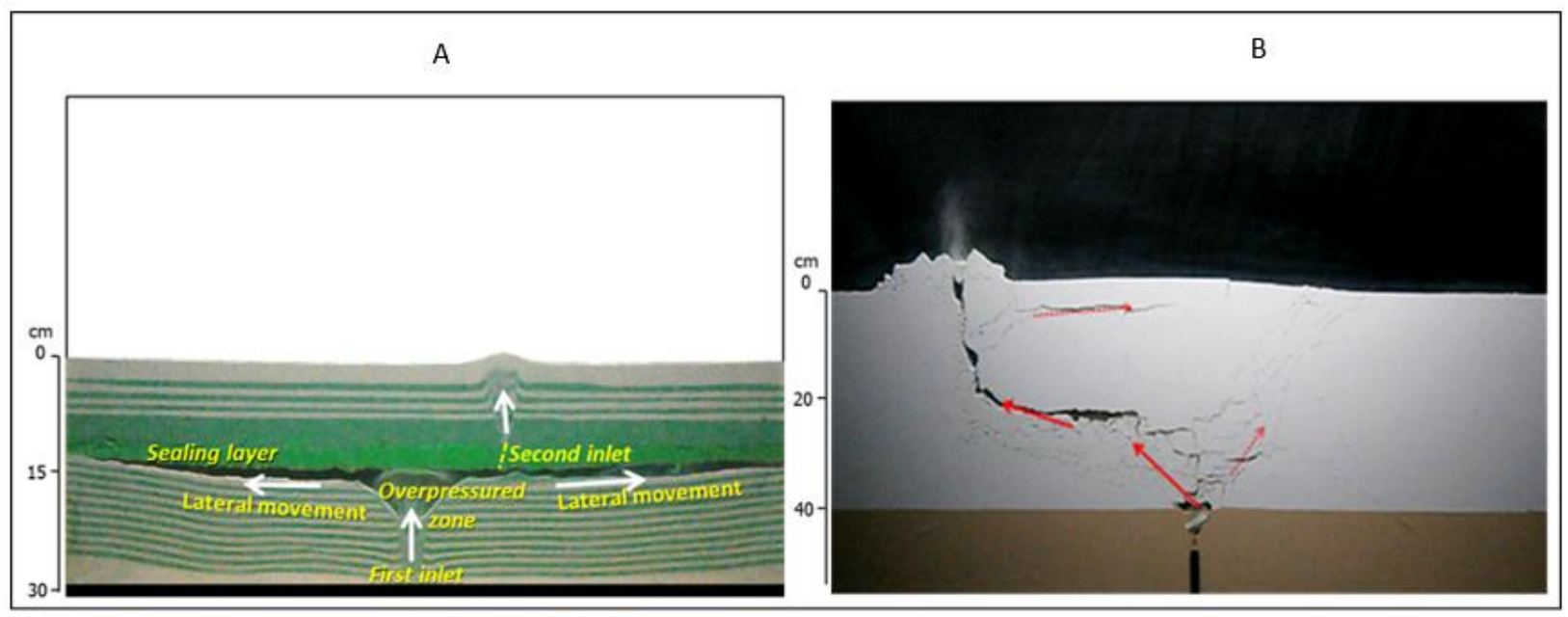

Fig. 12: (A) Detailed figure of the movement of the overpressure material. (B) overpressured material moves along weak zones, even in a homogeneous material (gypsum), probably controlled by differences in gypsum compaction at the middle and edges.

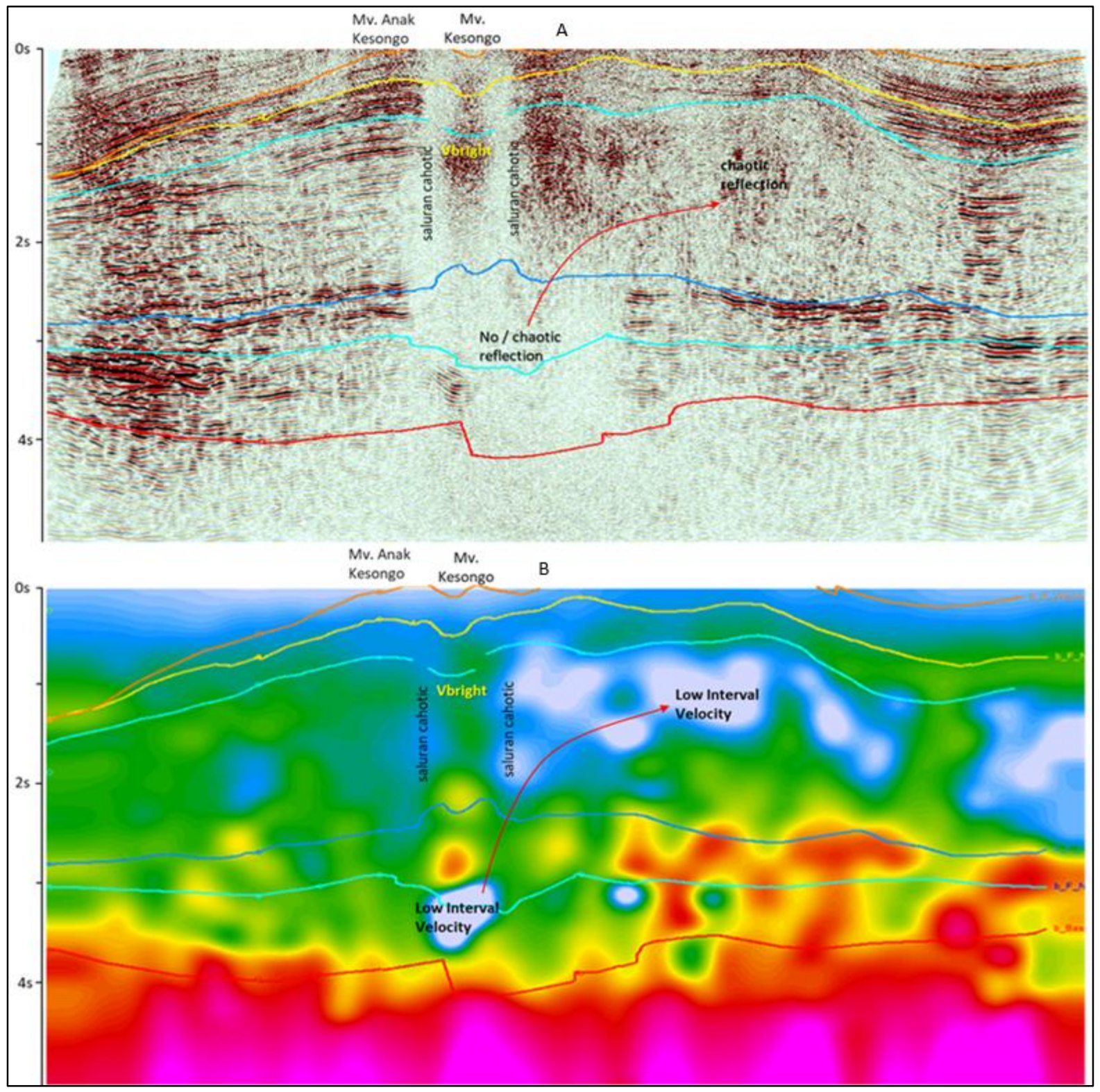

Fig. 13: (A) Seismic cross-section, random reflection channel pattern, V-bright, and random/chaotic reflection. (B) Velocity interval section, white is the lowest velocity while red-purple are high velocity (Burhannudinnur et al., 2021) 


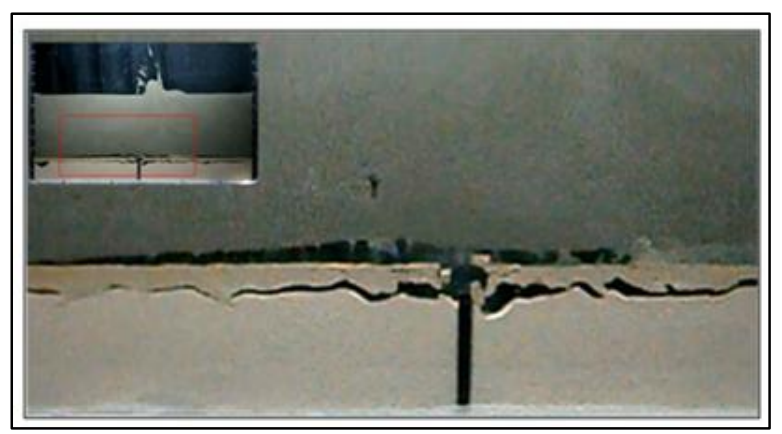

Fig. 14: The high-pressure zone H-S model pushes the sealing layer (thick mud) upward forms an anticline structure at the bottom seal layer. The model shows the high-pressure layer unable to break through the seal, $\mathrm{h}=30 \mathrm{~cm}$, at $\mathrm{P}=17 \mathrm{kPa}(2.5 \mathrm{psi})$.

\section{Conclusion}

The critical phase and the pressure structure pattern characteristics are shown in the dome structure pattern as the fluidization zone becomes shallower than the source. Each material's pressure structure geometry shows a consistent pattern, with differences in only the fault and pressure structure densities. In addition, the H-S experiment's validation with seismic interpretation shows the same geometry in the form of pressure structures and valve faults as a migration path from the mud volcano system. The valve's geometry and fault pattern are only observable in quartz or gypsum sand, but not the mud Thus, H-S modeling is suitable for validating the fan-like fault structure's geometric pattern in a mud volcano system at seismic.

\section{Acknowledgments}

Acknowledgments are addressed to the Department of Geological Engineering, FTKE Trisakti University, and the authors' colleagues who cannot be mentioned one by one who has provided input and discussions, PT. Pertamina EP for the research permission, all parties who helped in this research.

\section{References}

Burhannudinnur, M., 2020. The Potentials Prediction of Kradenan and Kesongo Mud Volcano Systems in East Java. Int. J. Adv. Sci. Technol. 29, 533-5 41.

Burhannudinnur, M., 2019. Mud gas play. J. Phys. Conf. Ser. 1402, 66022. https://doi.org/10.1088/1742$6596 / 1402 / 6 / 066022$

Burhannudinnur, M., 2012. Komplek Mud Volcano Kradenan, in: Proceeding PIT IAGI Yogyakarta 2012 The 41st IAGI Annual Convention and Exhibition. pp. 207-2011.

Burhannudinnur, M., Karyono., Sudradjat, A., 2021. Gunung lumpur dan fenomena lumpur Sidoarjo, Pertama. ed. CV. Galeripadi, Jakarta/Bandung.

Burhannudinnur, M., Noeradi, D., Sapiie, B., Abdassah, D., 2012. Karakater Mud Volcano di Jawa Timur, in: Proceeding PIT IAGI Yogyakarta 2012 The 41st IAGI Annual Convention and Exhibition. pp. 201-206.

Istadi, B.P., Wibowo, H.T., Sunardi, E., Hadi, S., Sawolo, N., 2012. Mud Volcano and Its Evolution, in: Imran
Ahmad Dar (Ed.), Earth Sciences. InTech, pp. 375434. https://doi.org/10.5772/24944

Johnsen, Ø., Toussaint, R., Måløy, K.J., Flekkøy, E.G.F., Shmittbuhl, F., 2008. Coupled air/granular flow in a linear Hele-Shaw cell. Phys. Rev. E. Stat. Nonlin. Soft Matter Phys. 771 Pt 1, 011301. https://doi.org/ 10.1103/PhysRevE.77.011301

Kusumastuti, A., Darmoyo, A.B., Suwarlan, W., Sosromihardjo, S.P.C., 1999. The Wunut Field: Pleistocene volcaniclastic gas sands in East Java, in: Proceedings of the 27th Annual Convention of the Indonesian PetroleumAssociation and Exhibition. Indonesian Petroleum Association, Jakarta, pp. 195215.

Letouzey, J., Werner, P., Marty, A., 1990. Fault reactivation and structural inversion. Backarc and intraplate compressive deformations. Example of the eastern Sunda shelf (Indonesia). Tectonophysic 183, 341362.https://doi.org/10.1016/0040-1951(90) 90425-8

Mazzini, A., Nermoen, A., Krotkiewski, M., Podladchikov, Y., Planke, S., Svensen, H., 2009. Strike-slip faulting as a trigger mechanism for overpressure release through piercement structures. Implications for the Lusi mud volcano, Indonesia. Mar. Pet. Geol. 26, 1751-1765. https://doi.org/10.1016/j.marpetgeo.2009.03.001

Nermoen, A., Galland, O., Jettestuen, E., Fristad, K., Podladchikov, Y., Svensen, H., Malthe-Sorenssen, A., 2010. Experimental and analytic modeling of piercement structures. J. Geophys. Res. Solid Earth 115, 1-15. https://doi.org/10.1029/2010JB007583

Rigord, P., Guarino, A., Vidal, V., Géminard, J., 2005. Localized instability of a granular layer submitted to an ascending liquid flow. Granul. Matter 7, 191-197. https://doi.org/10.1007/s10035-005-0214-1

Sapiie, B., Hadiana, M., 2007. Mechanism of some rift basins in Western Indonesia, in: Proceedings of 31st Annual Convention of the Indonesian PetroleumAssociation and Exhibition. Indonesian Petroleum Association, Jakarta.

Satyana, A.H., Asnidar, 2008. Mud Diapirs and Mud Volcanoes in Depressions of Java to Madura: Origins, Natures, and Implications to Petroleum System, in: Proceedings of 32nd Annual Convention of the Indonesian PetroleumAssociation and Exhibition. Indonesian Petroleum Association, Jakarta.

Sawolo, N., Sutriono, E., Istadi, B.P., Darmoyo, A.B., 2009. The LUSI mud volcano triggering controversy: Was it caused by drilling? Mar. Pet. Geol. 26, 1766-1784.

Talbot, C.J., 1995. Molding of Salt Diapirs by Stiff Overburden, in: Jackson, MPS; Roberts, DG; Snelson, S. (Ed.), Salt Tectonics: A Global Perspective: AAPG Memoir 65. The American Association of Petroleum Geologists, pp. 61-75.

Tingay, M., 2014. Initial pore pressures under the Lusi mud volcano, Indonesia. Interpretation 3, SE33-SE49. https://doi.org/10.1190/int-2014-0092.1

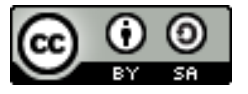

(C) 2021 Journal of Geoscience, Engineering, Environment, and Technology. All rights reserved. This is an open-access article distributed under the terms of the CC BY-SA License (http://creativecommons.org/licenses/bysa/4.0/). 